\title{
Manufacturing of Clayey Bricks by Synergistic Use of Waste Brick and Ceramic Powders as Partial Replacement of Clay
}

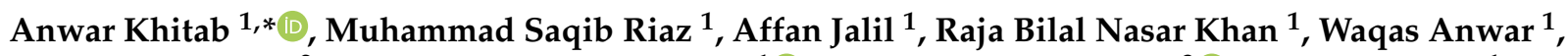 \\ Riaz Akhtar Khan ${ }^{2}$, Muhammad Tausif Arshad ${ }^{1}{ }^{1}$, Mehmet Serkan Kirgiz ${ }^{3}{ }^{\circledR}$, Zeesshan Tariq ${ }^{1}$ \\ and Seemab Tayyab ${ }^{1}$
}

check for updates

Citation: Khitab, A.; Riaz, M.S.; Jalil, A.; Khan, R.B.N.; Anwar, W.; Khan,

R.A.; Arshad, M.T.; Kirgiz, M.S.; Tariq,

Z.; Tayyab, S. Manufacturing of

Clayey Bricks by Synergistic Use of

Waste Brick and Ceramic Powders as

Partial Replacement of Clay.

Sustainability 2021, 13, 10214. https://

doi.org/10.3390/su131810214

Academic Editors: Rui Zhao,

Tianxue Yang and Sebastiano Patti

Received: 25 July 2021

Accepted: 7 September 2021

Published: 13 September 2021

Publisher's Note: MDPI stays neutral with regard to jurisdictional claims in published maps and institutional affiliations.

Copyright: (c) 2021 by the authors. Licensee MDPI, Basel, Switzerland. This article is an open access article distributed under the terms and conditions of the Creative Commons Attribution (CC BY) license (https:/ / creativecommons.org/licenses/by/ $4.0 /)$.
1 Department of Civil Engineering, Mirpur University of Science and Technology, Mirpur 10250, Pakistan; msaqibriaz11@gmail.com (M.S.R.); affan.ct@must.edu.pk (A.J.); bilal.ce@must.edu.pk (R.B.N.K.); waqas.ce@must.edu.pk (W.A.); tausif.ce@must.edu.pk (M.T.A.); zeeshan.ct@must.edu.pk (Z.T.); tayyabseemab14@gmail.com (S.T.)

2 Department of Civil Engineering, Lahore Leeds University, Lahore 54792, Pakistan; riaz.akhtar@ucet.edu.pk 3 Department of Architecture, Engineering-Architecture Faculty, Nişantaşi University, Istanbul 34398, Turkey; kirgiz@hacettepe.edu.tr

* Correspondence: anwar.ce@must.edu.pk

\begin{abstract}
Clay bricks are extensively used as building material worldwide. Natural soil deposits are in constant reduction due to the frequent use of clay to manufacture bricks. About 1600 billion bricks are produced annually by the consumption of millions of tons of natural resources. The prime focus of this study is to assess the feasibility of using a composite mixture of waste brick powder (WBP) and waste ceramic powder (WCP) as a replacement for depleting natural resource "clay" in brick manufacturing. Based upon the previous studies, the replacement levels were kept as $(4+5) \%$, $(8+10) \%$, and $(12+15) \%$ of WCP and WBP, respectively. The brick specimens were evaluated in terms of compressive strength, modulus of rupture, density, water absorption, efflorescence, apparent porosity, resistance to chemical attack and sulfate attack, and freeze-thaw resistance. The study reveals that about $27 \%$ of clay can be replaced with ceramic waste powder and waste brick powder, which can preserve a massive amount of natural clay without compromising the quality of the bricks.
\end{abstract}

Keywords: bricks; clay; recycling; waste brick powder; waste ceramic powder; sustainable development

\section{Introduction}

The construction industry plays a vital role in the socio-economic development of any country [1]. Nevertheless, it is also a significant source of greenhouse gas emissions and depletion of natural resources. A shift in the construction approach towards sustainable development is the critical need of the day. In construction projects, bricks are extensively used as they possess beneficial properties like ease of handling, high durability, and low cost [2]. They are used in almost every type of civil engineering project, including commercial, industrial, and residential. The primary raw material used for the manufacturing of bricks is clay. Every year almost 340 billion tons of clay are consumed worldwide to manufacture bricks, and in Pakistan, about 59 billion bricks are produced in 1200 brick kilns [3]. Brick manufacturing involves collecting, mixing, molding, drying, and burning raw materials in brick kilns. Bricks are usually composed of various types of clays and other ingredients like sand. Clays suitable for brick manufacturing usually comprise 20-30\% alumina, 50-60\% silica, 1-5\% lime, and 5-6\% iron oxide, along with various other carbonates and oxides in minor quantities [4]. The mineralogical composition of the clay is important for the quality of the end product. Carbonates lead to the formation of pores when bricks are manufactured at a temperature of $800-1000{ }^{\circ} \mathrm{C}$ [5], alkalis (Na and $\mathrm{K}$ salts) absorb moisture from the atmosphere and lead to dampness and efflorescence [6], quartz mainly acts as a filler and maintains the shape of the bricks and improves the mechanical 
properties [7], and iron oxide (hematite or magnetite) is responsible for the color and strength of the bricks [8]. It is imperative to have a clear understanding of different types of waste that can be used in brick manufacturing to partially replace clay.

The properties of bricks are greatly affected by the following factors:

(a) Properties of raw material used

(b) Manufacturing techniques

(c) Temperature

Many researchers have forecasted that natural soil deposits are on a constant decline because of the large quantity of production of clayey bricks and ceramic tiles worldwide. Countries like Pakistan are also facing the issue of disturbance in the natural balance of fertile soil due to the manufacturing of large quantities of bricks throughout the year. This issue sometimes becomes more critical due to the lack of an efficient solid waste management system. Developing countries with struggling economies are adversely affected by the hazardous impacts of unmanaged solid waste generated from domestic and commercial activities. This waste is a potential threat to environmental sustainability and human health Recycling wastes addresses environmental concerns and is also an economically viable approach towards environmentally friendly construction. Many researchers in the past have used many other waste materials. In the following paragraph, a brief introduction is presented.

Andreola et al. studied clay recycling via rice husk ash (RHA) [9]. Their study revealed that RHA produces lightweight bricks with low strength. A $5 \%$ replacement as the optimum percentage for load-bearing purposes was reported. Kazmi et al. replaced clay with sugarcane bagasse ash [10] and showed that the replacement leads to lighter bricks with lower compressive and flexural strengths. Ibrahim et al. used sawdust to partially replace clay $(0-10 \%)$ [11]. It was concluded that the replacement leads to lighter bricks but with a drastic reduction in compressive strength from 14.5 to $6.7 \mathrm{MPa}$ at a $10 \%$ substitution level. Ahmed et al. studied the effect of coal and wheat husk additives on the properties of clayey bricks [12]. It was demonstrated that both the additives induce porosity and reduce strength. Munir et al. used waste marble powder (WMP) as a partial replacement of clay in bricks [13] and confirmed a subsequent strength reduction and increased porosity. Mandal et al. used iron slime as an additive in making bottom ash bricks [14]. The addition enhanced both strength and density. Riaz et al. added WBP to partially replace clay to manufacture eco-friendly bricks [15]. The addition led to lightweight porous bricks with reduced strength. Riaz et al. incorporated WCP as a partial replacement of clay in making clayey bricks [4]. The incorporation resulted in bricks with enhanced strength as well as weight. Hasan et al. investigated the effect of the partial replacement of clay by waste glass [15]. Their findings revealed that the replacement increases compressive strength and density. All the above research indicates that the partial replacement of clay by any one material reduces strength and weight or increases both. Keeping that in mind, it would be logical to use binary or ternary mixes instead of unary ones. For example, Li et al. used iron ore tailing (IOT) to prepare bricks [16]. The addition increased not only the strength but also the weight due to the heavier density of iron. In order to induce different porosity and reduce weight, they used foam gel casting technology. In the same way, Quero et al. used a binary mixture (screened clay + fly ash (FA)) as a partial replacement of clay in brick manufacturing and reported products with enhanced porosity and compressive strength [17].

Besides the bricks, recycling waste materials has been investigated in ceramic tiles and traditional ceramics. In this regard, significant work has been carried out by Jordan et al. [18] and Montero et al. [19,20]. Sludge rich in calcium carbonate was successfully utilized in traditional ceramics as a secondary raw material, resulting in significant cost savings [20]. The beneficial use of sewage sludge and marble residues in ceramic tile was also corroborated [19], wherein the reactivity of added residues (sewage sludge and marble sludge) with the clay minerals and quartz was shown. 
The focus of this study is to introduce environmentally friendly bricks that are durable and sustainable and help preserve the natural environment. Existing research findings on waste utilization in brick manufacturing were carefully reviewed to develop a base for the study. An effort has been made to devise new ways to preserve natural clay by replacing it with waste ceramic powder (WCP) and waste brick powder (WBP) in the manufacturing of bricks. The present study is based on some previous work conducted in our research group. In one study, clay was partially replaced by WBP in the range of 5-15\% - the resulting bricks were lightweight but had lower mechanical strength than the control specimens [21]. In the other study, the clay was replaced by WCP in the range of 4-12\% - the modified bricks exhibited high density with higher mechanical strength. In this study, a composite replacement of WCP and WBP, i.e., $4+5 \%, 8+10 \%$, and $12+15 \%$ WCP and WBP, respectively, is proposed. The goal is to produce bricks with acceptable density, durability, and mechanical strength (comparative to those of the control products) by using the composite advantage of the proposed binary mix. This would also ensure efficient utilization of wastes generated from two different resources.

\section{Materials and Methods}

All laboratory work was carried out at a temperature of $20 \pm 2{ }^{\circ} \mathrm{C}$. Raw materials used in this research are fresh clay, waste bricks from demolished masonry, and waste ceramic from broken ceramic pottery. Clay was collected from local natural resources, and the wastes were ground to a fine powder in the laboratory milling machine. The oxide compositions of clay, waste brick powder, and waste ceramic powder were determined by the standard X-ray fluorescence technique and are shown in Table 1.

Table 1. Oxide composition of the materials.

\begin{tabular}{ccccc}
\hline & Clay & WCP & WBP & Recommended for Bricks [4] \\
\hline $\mathrm{SiO}_{2}$ & 59.227 & 71.004 & 46.362 & $50-60$ \\
$\mathrm{Al}_{2} \mathrm{O}_{3}$ & 16.608 & 21.877 & 29.723 & $20-30$ \\
$\mathrm{Fe}_{2} \mathrm{O}_{3}$ & 6.947 & 1.169 & 7.78 & $5-6$ \\
$\mathrm{SO}_{3}$ & - & - & 5.174 & - \\
$\mathrm{CaO}$ & 13.108 & 3.682 & 4.858 & $1-5$ \\
$\mathrm{TiO}_{2}$ & 0.885 & 1.104 & 3.929 & - \\
$\mathrm{K}_{2} \mathrm{O}$ & 2.92 & 0.374 & 1.86 & - \\
\hline
\end{tabular}

The composition revealed that the clay used for brick manufacturing has $\mathrm{CaO}$ above the recommended limits. Therefore, the lower percentages of $\mathrm{CaO}$ in the waste materials present an extra advantage in limiting the overall $\mathrm{CaO}$ content of the mix. Similarly, the higher $\mathrm{SiO}_{2}$ content in WCP is compensated by a lower one in WBP. The lower content of $\mathrm{Fe}_{2} \mathrm{O}_{3}$ in WCP is reinforced by the higher ones in clay and WBP. Overall, the oxide contents seem suitable for a good mix for clayey bricks.

The particle shape and sizes were determined using the Nova Nano SEM 450 fieldemission scanning electron microscope (FE-SEM) under standard laboratory conditions. The microscopic images of clay, WCP, and WBP are shown in Figure 1.

The microscopic images reveal that the clay consisted of a wide range of particles, from a smaller tubular shape to a larger irregular shape with rough edges. The WCP particles were irregular in shape, with rough edges. However, the sizes of different particles were in a comparable range, whereas the particles of WBP were thinner in size and seemed to be porous. At first glance, it appears that whereas the WCP particles should result in denser mixes, the WBP particles should induce more porosity and result in lighter end products. This was evidenced in the previous studies of our group, where WBP resulted in porous lighter bricks with reduced strength and WCP produced heavier bricks with enhanced strength. 

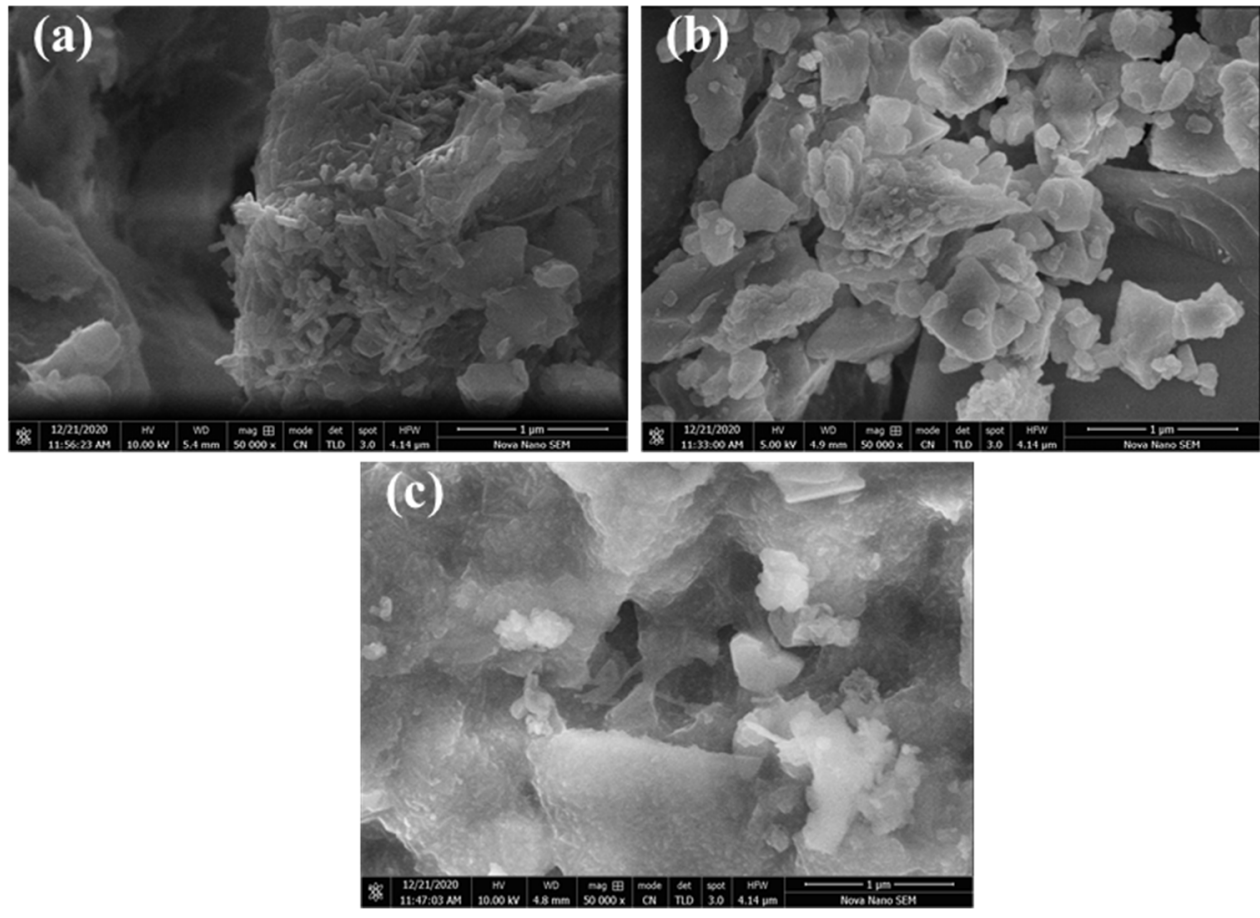

Figure 1. Microscopic images: (a) clay, (b) WCP, (c) WBP.

X-ray powder diffraction is a widely used technique for the identification of crystalline and amorphous phases in raw materials. XRD patterns of clay, waste brick powder (WBP), and ceramic waste powder (WCP) were determined using Bruker D2-Phaser and are shown in Figure 2.

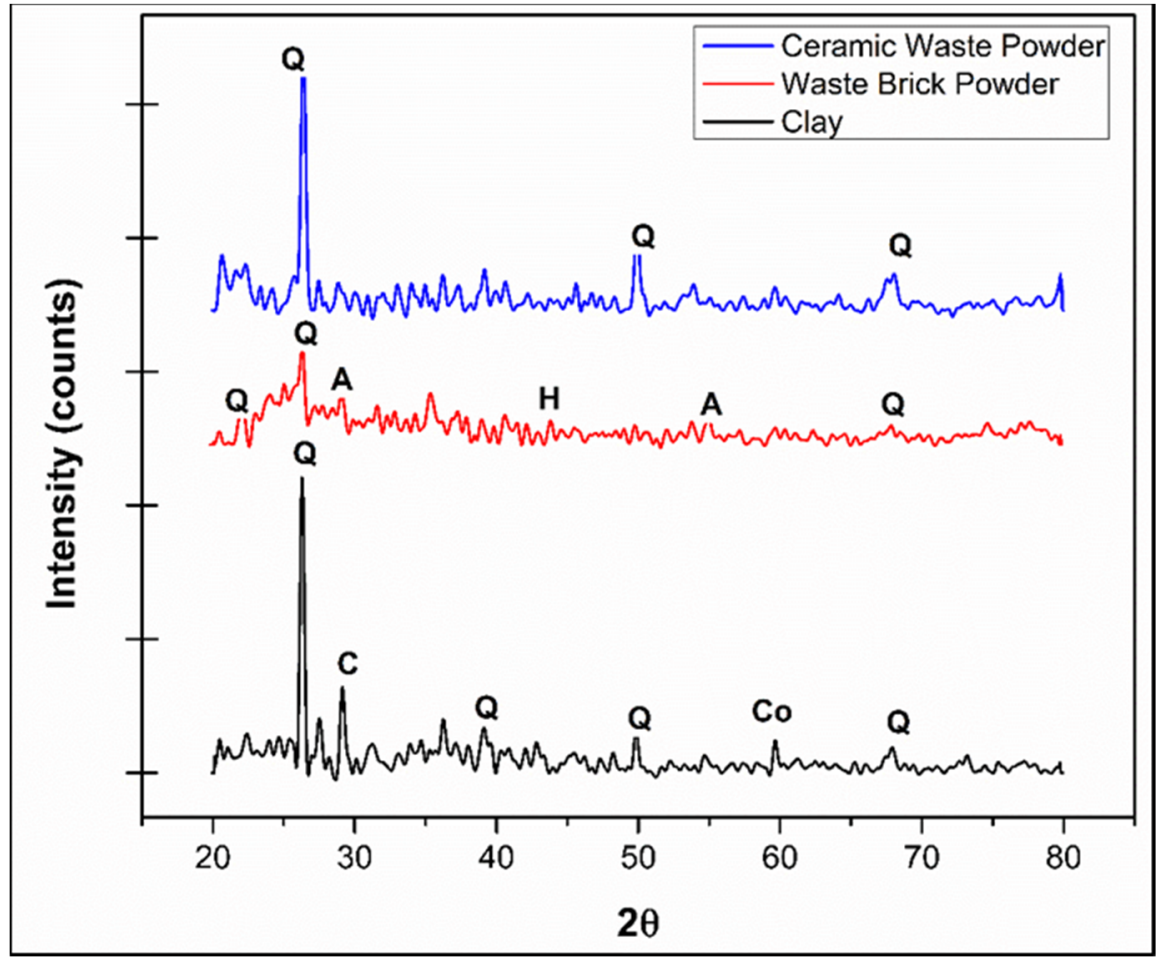

Figure 2. XRD patterns of raw materials.

Distinctive peaks of $\mathrm{Q}\left(\right.$ quartz $\left.\left(\mathrm{SiO}_{2}\right)\right), \mathrm{C}\left(\right.$ calcite $\left.\left(\mathrm{CaCO}_{3}\right)\right)$, and $\mathrm{Co}$ (corundum $\left(\mathrm{Al}_{2} \mathrm{O}_{3}\right)$ ) minerals were identified in clay, which were mainly crystalline. This is in agreement with 
the findings reported earlier [22,23]. The crystal structure of WBP was found to be somewhat different. $\mathrm{H}$ (hematite $\left.\left(\mathrm{Fe}_{2} \mathrm{O}_{3}\right)\right)$, quartz $\left(\left(\mathrm{SiO}_{2}\right)\right.$, muscovite $\left(\mathrm{KAl}_{2}\left(\mathrm{AlSi}_{3} \mathrm{O}_{10}\right)(\mathrm{OH})_{2}\right)$, and $\mathrm{A}$ (albite $\left.\left(\mathrm{Na}\left(\mathrm{AlSi}_{3} \mathrm{O}_{8}\right)\right)\right)$ minerals were found. The clay peaks were more intense than those observed for WBP, whereas the WBP had a somewhat more amorphous structure. This is also corroborated by the XRD results shown earlier for WBP [24], where $27.08 \%$ of the phases were found to be amorphous. The XRD of WCP showed that the detected predominant peaks were noticeably present between the 2-theta values of $20^{\circ}$ to $30^{\circ}$ and $50^{\circ}$ to $55^{\circ}$, signifying the presence of quartz $\left(\mathrm{SiO}_{2}\right)$, as was also found for clay and WBP.

Bricks were prepared by replacing clay with different percentages $((4+5) \%,(8+10) \%$, $(12+15) \%)$ of the binary composite of WCP and WBP. A total of 150 bricks were cast, which included 50 samples for each category. Numbering and relevant composition are shown in Table 2.

Table 2. Marking of samples and material composition.

\begin{tabular}{ccccc}
\hline Scheme & Name & Clay (\%) & (WCP + WBP) (\%) & No. of Bricks \\
\hline 5 & C45 & 91 & $4+5$ & 50 \\
6 & C 810 & 82 & $8+10$ & 50 \\
7 & C1215 & 73 & $12+15$ & 50 \\
\hline
\end{tabular}

All the ingredients were passed through ASTM sieve \#4 to minimize the inclusion of coarser particles in the mix. All the materials were homogeneously mixed following the proportions described in Table 2. The mixing, watering, and molding processes were carried out in the laboratory at a temperature of $20 \pm 2{ }^{\circ} \mathrm{C}$ and are shown in Figure 3. As shown in the figure, the proposed mixture resulted in the same plasticity, ease of handling, and uniformity as the control specimens with $100 \%$ clay. About $50 \mathrm{~L}$ of water was added to a mix of $150 \mathrm{~kg}$ for adequate plasticity and consistency. Bricks were manufactured as per Pakistan standard sizes of $9 \times 4 \frac{1}{2} \times 3$ inch $(225 \times 113 \times 75 \mathrm{~mm})$ for ordinary masonry works $[25,26]$. The bricks were air-dried for 14 days. Afterward, they were shifted to a Bull's trench kiln and were dried for 21 days. The temperature was kept at $800{ }^{\circ} \mathrm{C}$ for $36 \mathrm{~h}$.

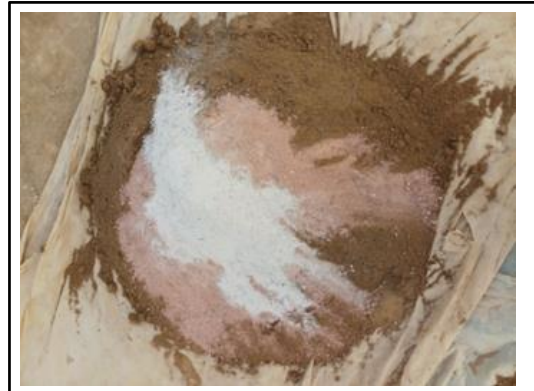

(a)

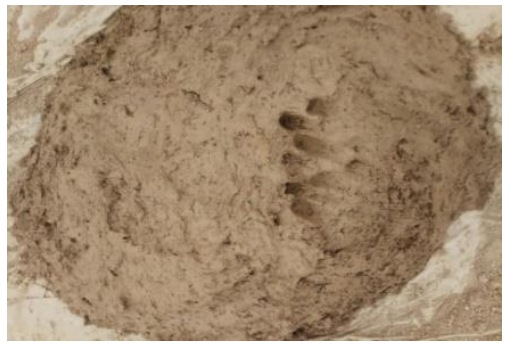

(c)

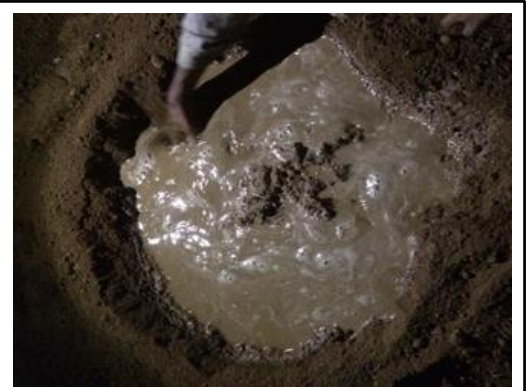

(b)

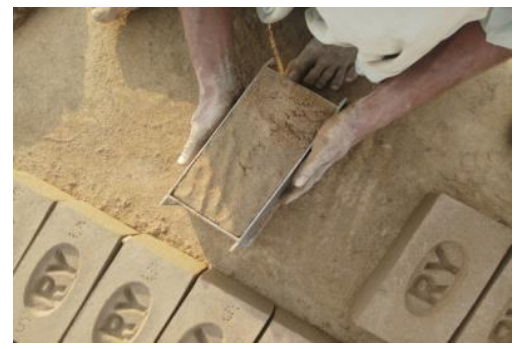

(d)

Figure 3. (a) Ingredients (clay (dark brown), WBP (light brown), WCP (white), (b) mixing water, (c) wet mix, (d) molding. 
Density was calculated using ASTM C67-17 [27]. The weight and dimensions of the specimen were measured after oven drying at $110^{\circ} \mathrm{C}$ for $24 \mathrm{~h}$. Density was calculated using Equation (1).

$$
\text { Density }=\frac{\mathrm{M}(\mathrm{g})}{\mathrm{V}\left(\mathrm{cm}^{3}\right)}
$$

The water absorption test was performed according to ASTM C67-17. The samples were kept in the oven at $110{ }^{\circ} \mathrm{C}$ for $24 \mathrm{~h}$, and then dry weight $\left(\mathrm{W}_{\mathrm{d}}\right)$ was measured. After that, the samples were kept in water for $24 \mathrm{~h}$, and saturated weight (Ws) was measured.

The water absorption value was calculated using Equation (2).

$$
\text { Water Absorption }(\%)=\frac{\mathrm{Ws}-\mathrm{Wd}}{\mathrm{Wd}} * 100
$$

The freeze-thaw resistance testing was performed according to ASTM C67-17. Cracks (if any) were observed carefully, and the initial dry weight (Wi) of the samples was measured after drying in the oven at $110^{\circ} \mathrm{C}$ for $24 \mathrm{~h}$. The samples were kept in water for $4.5 \mathrm{~h}$ and then $20 \pm 2 \mathrm{~h}$ in the freezer, and this process was continued for 50 cycles. After the completion of 50 cycles, the oven-dried weight of the samples was measured $\left(\mathrm{W}_{\mathrm{f}}\right)$. Weight loss was calculated using Equation (3).

$$
\text { Weight Loss } \%=\frac{\mathrm{Wi}-\mathrm{wf}}{\mathrm{Wi}} * 100
$$

The efflorescence experiment was performed according to ASTM C67-17. The bricks were partially submerged in water for seven days. After that, the presence of salts on the surface of the bricks was observed.

A sulfate attack test was performed according to ASTM C 1012 [28]. The bricks were submerged in a $10 \%$ solution of sodium sulfate for one month. Afterward, their compression strength was measured. ASTM C_67-17 was used to check the chemical resistance of the bricks. The bricks were dipped in $\mathrm{HCL}$ and $\mathrm{KOH}$ for 3 hours, and a change in color and texture was observed.

The modulus of rupture (MOR) or flexural strength is the maximum bending stress a material can bear. It is more or less related to compressive strength [29]. The MOR test of the bricks was performed according to ASTM C67-17, using Controls EN-Standard Automatic Compression Testers for Cubes and Cylinders Wizard Auto. The test was conducted by the three-point loading method at a slow loading rate. The MOR was calculated according to Equation (4).

$$
\text { MOR }=3 \mathrm{P}\left(\frac{\mathrm{L}}{2}-\mathrm{x}\right)
$$

A compressive strength test was performed according to ASTM C67-17 using Controls EN-Standard Automatic Compression Testers for Cubes and Cylinders Wizard Auto. Gypsum was used for the capping of the bricks. The compressive strength was calculated from the load at failure and the surface area in accordance with Equation (5).

$$
\text { Compression Strength }(\mathrm{MPa})=\frac{\mathrm{P}(\mathrm{N})}{\mathrm{A}(\mathrm{mm} 2)}
$$

The water absorption rate was performed according to ASTM C67-17. For the initial water absorption rate, the bricks were oven-dried and weighted $\left(\mathrm{W}_{\mathrm{i}}\right)$, then partially submerged in water for 1 minute and weighted $\left(\mathrm{W}_{1 \mathrm{~min}}\right)$. The initial rate of water absorption was calculated using Equation (6).

$$
\text { Initial Rate of Water Absorption }=\frac{\mathrm{W} 1 \mathrm{~min}-\mathrm{Wi}}{\mathrm{Wi}} * 100
$$


The apparent porosity test was performed according to ASTM C20 [30]. The bricks were oven-dried and weighted $\left(\mathrm{W}_{\mathrm{d}}\right)$. After that, the bricks were submerged in boiling water to open the pores and 6 hours in normal water to saturate them and then weighted $\left(\mathrm{W}_{\text {sat }}\right)$. They were further submerged in water and the suspended weight was measured $\left(\mathrm{W}_{\mathrm{s}}\right)$. The porosity was calculated using Equation (7).

$$
\% \text { age Porosity }=\frac{\text { Volume of Voids }}{\text { Volume of Brick sample }} * 100
$$

\section{Results and Discussion}

\subsection{XRD of Brick Specimens}

XRD analysis of the brick specimens was carried out to determine the changes in mineralogical composition and crystal structure after sintering at high temperatures $\left(850^{\circ} \mathrm{C}\right)$. The results are given in Figure 4. The different sets of specimens-one containing WCP only (C12 and C4, containing $12 \%$ and $4 \% \mathrm{WCP}$, respectively) and the other containing a blend of WCP and WBP-exhibited different peaks in the X-Ra diffractograms. Apparent quartz $(Q)$ mineral as the primary crystalline phase was identified in all the samples. Certain broad humps, as seen in the XRD of the raw powders, disappeared, indicating the decomposition of phase from amorphous to crystalline. In the XRD patterns of the brick samples containing WCP and WBP, hematite $(\mathrm{H})$ and albite $(\mathrm{A})$ were also identified. These phases are the main mineral framework of the fired clay bricks and are responsible for the physical properties and mechanical strength of bricks [31].

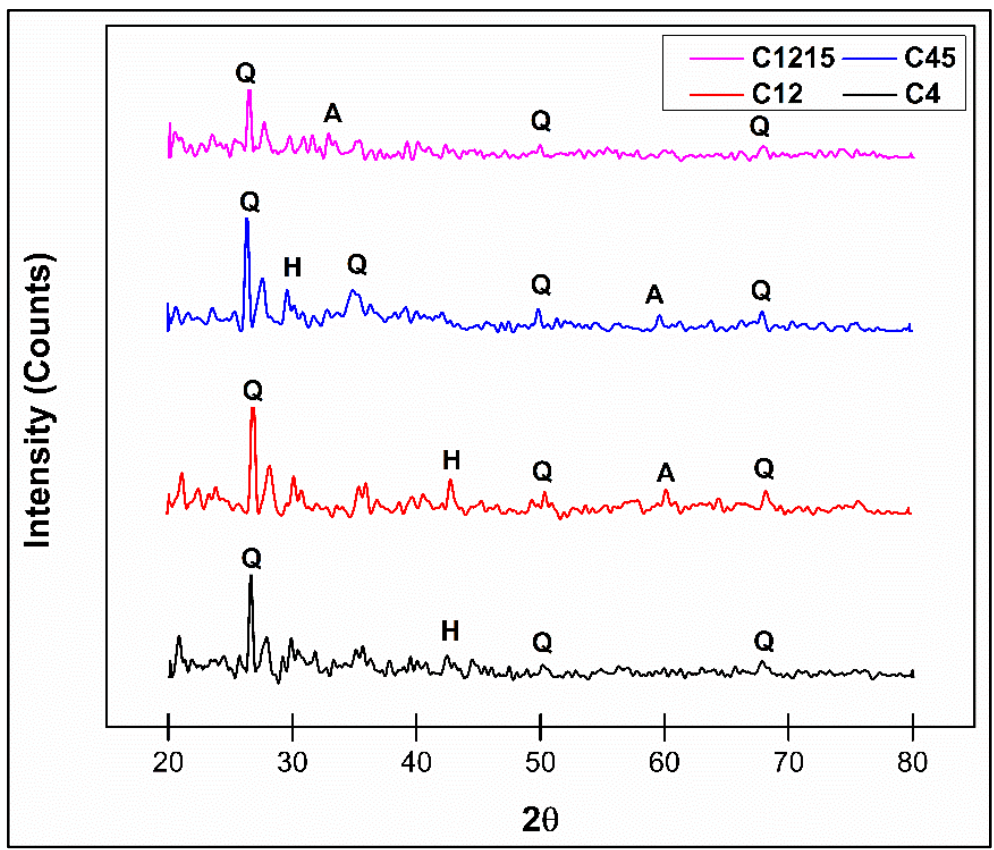

Figure 4. XRD patterns of the bricks.

\subsection{Physical Properties}

\subsubsection{Density}

The density of bricks is an important property, as it helps designers estimate the overall weight of the structure. Densities or weights of common bricks are usually mentioned in regional/local building codes. The densities obtained in the current study are presented in Figure 5. The results show that overall, the partial replacements did not significantly lower or enhance the density of the bricks. Moreover, even an overall partial replacement of $27 \%$ clay by WCP and WBP conserved the same density as the control. Comparatively, the highest density was obtained in C45 and the lowest density in C1215. The microscopic image of the C45 brick specimen is shown in Figure 6, revealing a densely packed material. 
Riaz et al. reported a density of $1.27 \mathrm{~g} / \mathrm{cc}$ and $1.4 \mathrm{~g} / \mathrm{cc}$ for the specimens with only $15 \%$ WBP and $12 \% \mathrm{WCP}$, respectively: The combined mixture $(12+15) \%$ resulted in a density of $1.42 \mathrm{~g} / \mathrm{cc}$, which was approximately equal to that of the control specimen. This shows that $27 \%$ hybrid mix produces bricks with the same density as those made of $100 \%$ clay. The density of common clayey bricks varies from country to country. Indian codes recommend a density of 1.6 to $1.92 \mathrm{~g} / \mathrm{cc}$ for ordinary clayey bricks [32]. Pakistani standards recommend a minimum weight of $3000 \mathrm{~g}$ for clayey bricks [25]. The average weight of the bricks during this study was found to be $2600 \mathrm{~g}$, which implies that the manufactured bricks were lighter in weight. Nevertheless, the lightweight bricks are advantageous in terms of the lower dead weight of the structures if mechanical and durability properties remain within the standard limits [33].

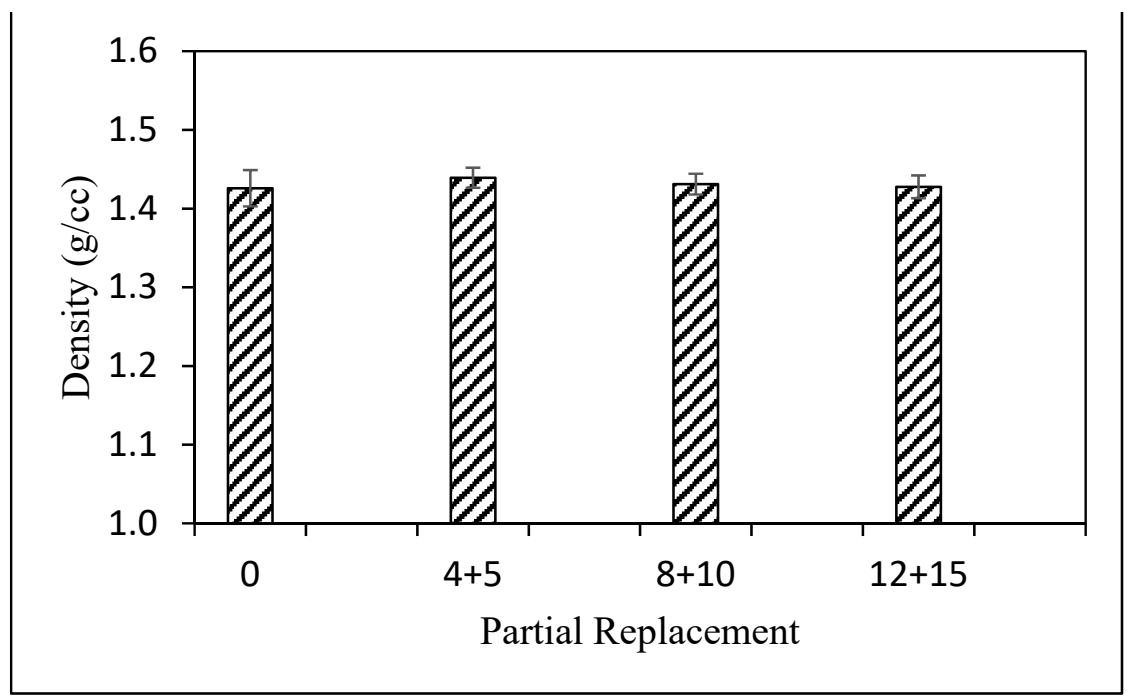

Figure 5. Variation of density as a function of replacement.

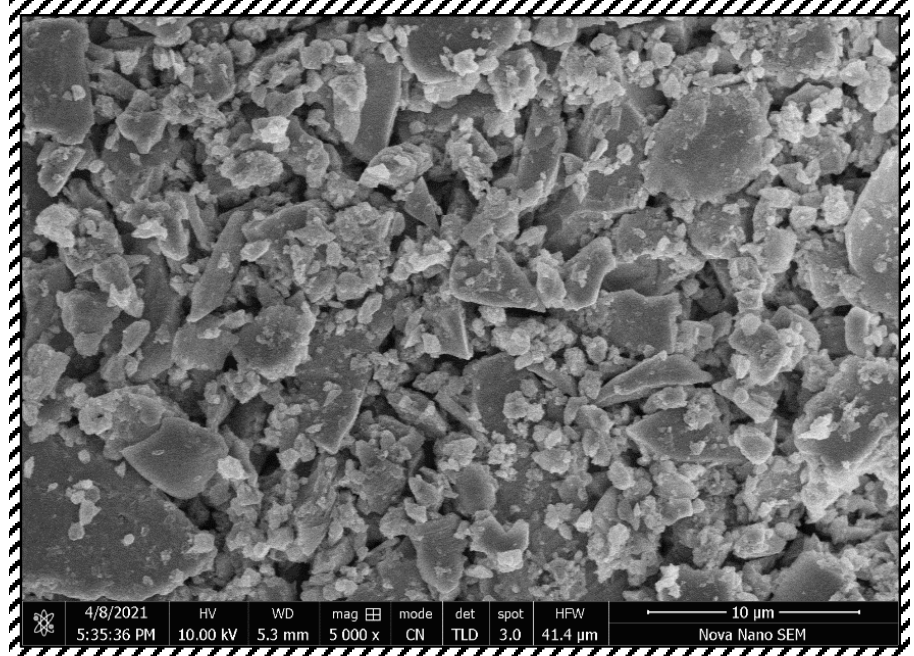

Figure 6. Microscopic image of $C 45$ showing density packed particle.

\subsubsection{Porosity}

The porosity of the bricks is an important property. Higher porosity ensures good insulation, and lower porosity typically leads to higher strength due to dense packing. Higher porosity (if pores are interconnected) is also an indicator of higher water absorption, adversely affecting durability. The porosity results are shown in Figure 7 . The results match with those of density in Figure 5. Overall, the density and porosity at all replacements remained in close range with those of the control specimen. However, with a slight increase 
in density, the porosity also slightly decreased, and vice versa. Riaz et al. reported a porosity of $38.3 \%$ and $33.2 \%$ for the specimens with only $15 \% \mathrm{WBP}$ and $12 \% \mathrm{WCP}$, respectively. The combined mixture $(12+15) \%$ resulted in a porosity of $35.1 \%$, which authenticates the synergic effect of the hybrid mixture. The porosity of the control specimens was $34.5 \%$, slightly lower than that of the $\mathrm{C} 1215$.

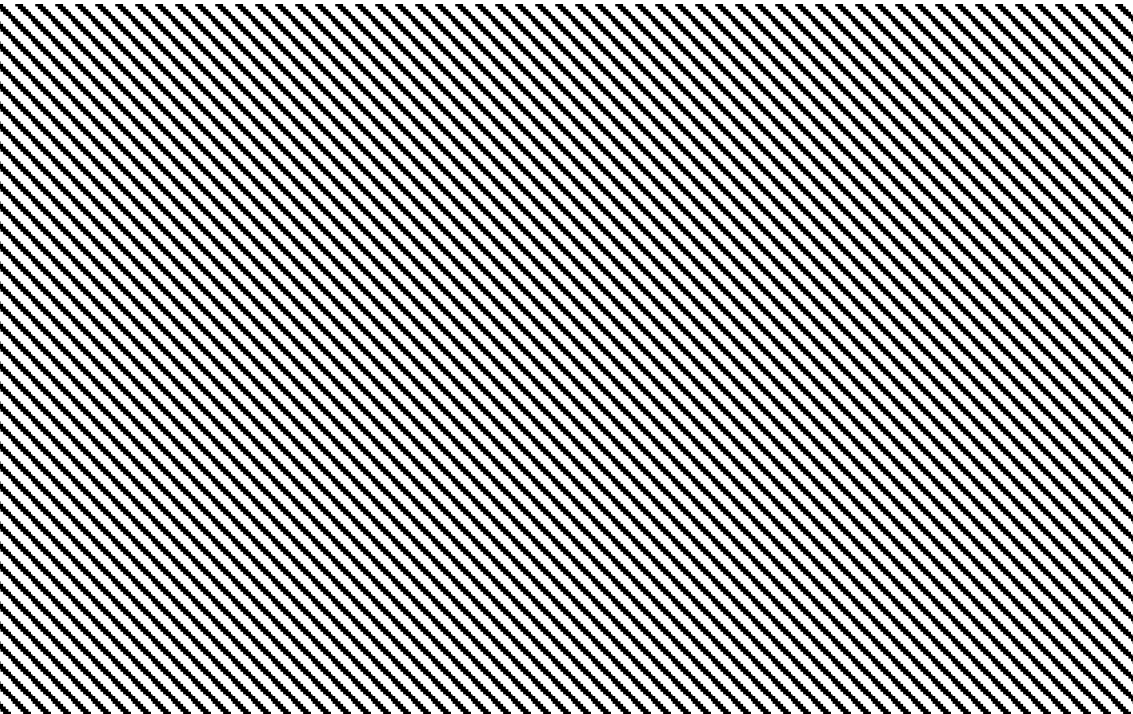

Figure 7. Variation of porosity with replacement.

\subsection{Durability Properties \\ 3.3.1. Water Absorption}

Water absorption of clayey bricks directly affects durability [34]. Higher water absorption levels are associated with risk of degradation when exposed to aggressive environments. The variation of water absorption with replacement is shown in Figure 8. The results are in close coordination with the density and porosity values. Riaz et al. reported a water absorption of $24.1 \%$ and $19.5 \%$ for the specimens with only $15 \% \mathrm{WBP}$ and $12 \% \mathrm{WCP}$, respectively. The combined mixture $(12+15) \%$ resulted in average water absorption of $23.1 \%$, which was slightly more than expected but equal to that of the control specimen containing only clay. Pakistani building standards recommend $20 \%$ water absorption for first-class bricks and $28 \%$ for second class [25]. As such, all the bricks lay in the second-class range. 


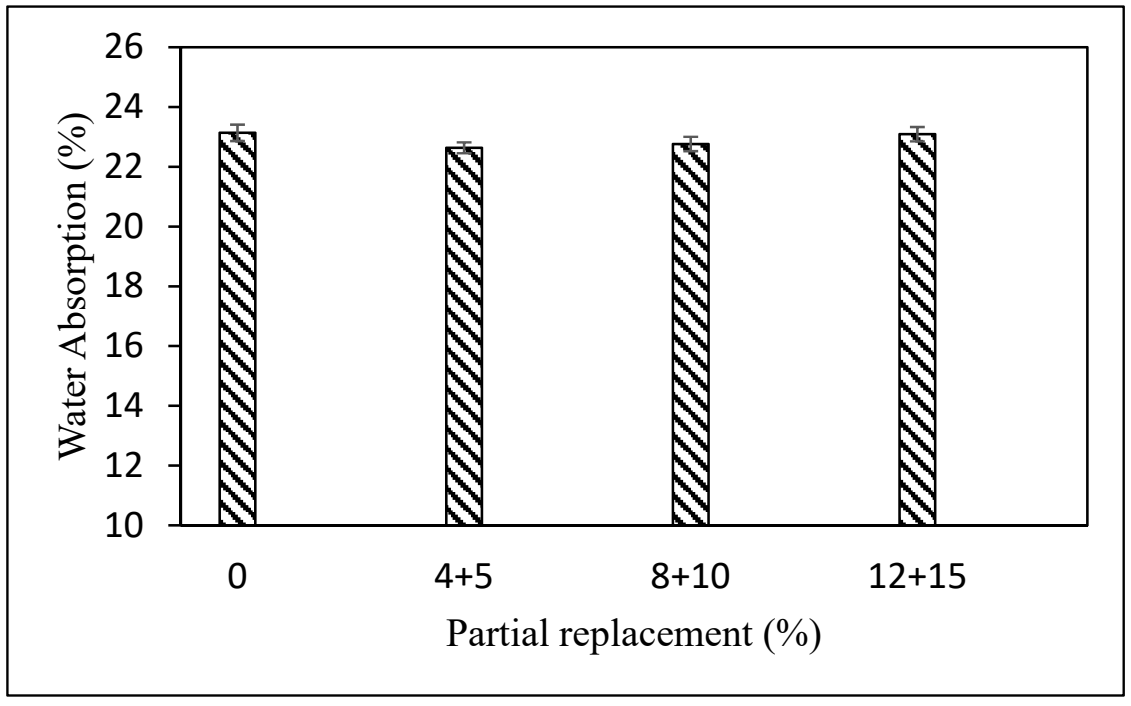

Figure 8. Variation of water absorption with replacement.

\subsubsection{Initial Rate of Water Absorption}

The variation of the initial rate of water absorption with partial replacement is shown in Figure 9.

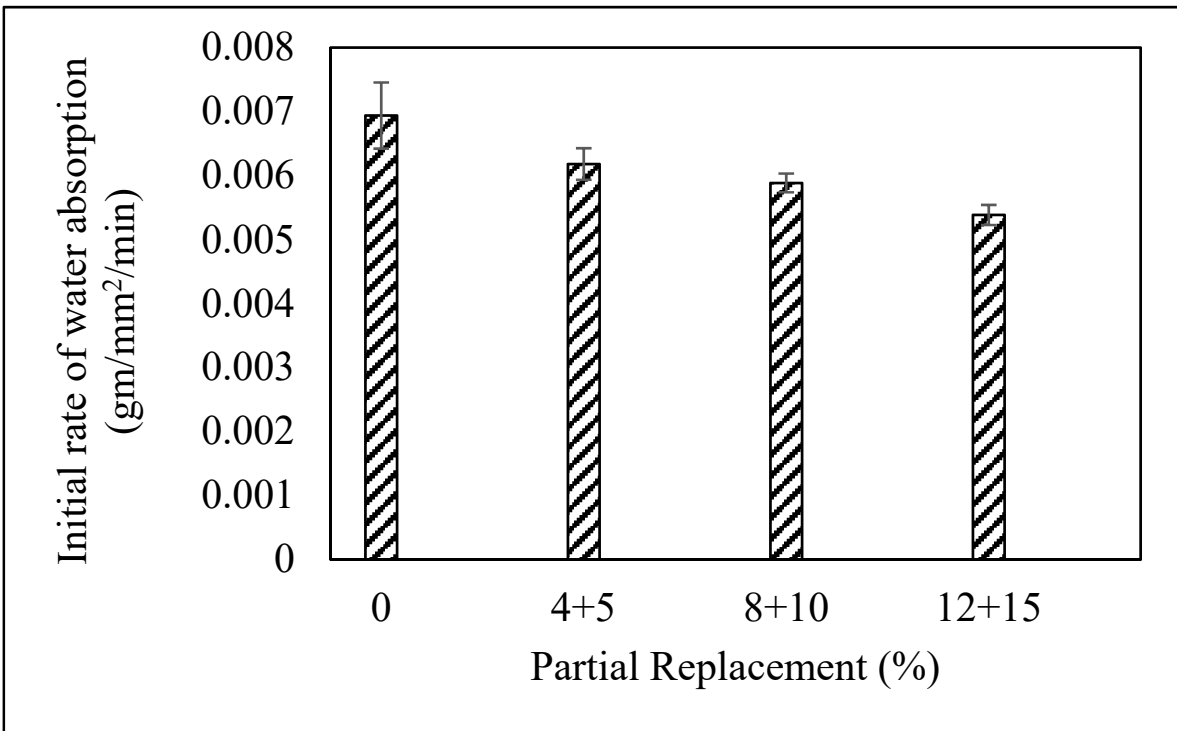

Figure 9. Variation of initial rate of water absorption with replacement.

The initial rate of absorption (IRA) values are not covered in the ASTM specification [35]. However, they are essential in the sense that they are a measure of how quickly the brick pulls away moisture from the overlying fresh mortar/plaster. The results show that IRA decreased with an increase in the percent replacement. According to Pavia et al., the IRA values should range between 0.00035 and $0.0036 \mathrm{~g} / \mathrm{mm}^{2} / \mathrm{min}$ [36]. The minimum IRA was obtained with C1215 specimens, which was about $0.0053 \mathrm{~g} / \mathrm{mm}^{2} / \mathrm{min}$. This indicates that the manufactured bricks should be properly wetted before laying.

\subsubsection{Efflorescence}

Efflorescence refers to the crystalline salt deposits that appear on the porous surface. Typical efflorescence is white but can vary in color, including yellow or brown, depending on the salt and accompanying chemicals. Common salts that lead to efflorescence include calcium sulfate, sodium sulfate, potassium sulfate, vanadyl sulfate, calcium carbonate, 
sodium carbonate, potassium carbonate, and manganese oxide. To examine efflorescence effects, the specimens were analyzed as per the ASTM C67-17 standard test. No efflorescence was observed in either the control or the modified bricks.

\subsubsection{Sulfate Attack}

When exposed to a sulfate environment, sulfate ions accumulate in the pores and exert stresses on the surrounding material. Consequently, the stresses generated by the sulfate crystals lead to the cracking of the material. The mechanism is analogous to that of chloride ingress in concrete, where chloride ions migrate inside concrete through pores and corroded steel, and the rust particles exert disruptive tensile stresses on the surrounding concrete [37]. ASTM C-67 was used to check the resistance to sulfate attacks in controlled and modified brick specimens. The bricks were immersed in a standard solution of sodium sulfate $(5 \mathrm{gm} / \mathrm{L})$ for 30 days, and the reduction in compressive strength was determined. The results are shown in Figure 10. The strength reduction decreased with an increase in replacement level, and the highest resistance to sulfate attack was seen in C1215.

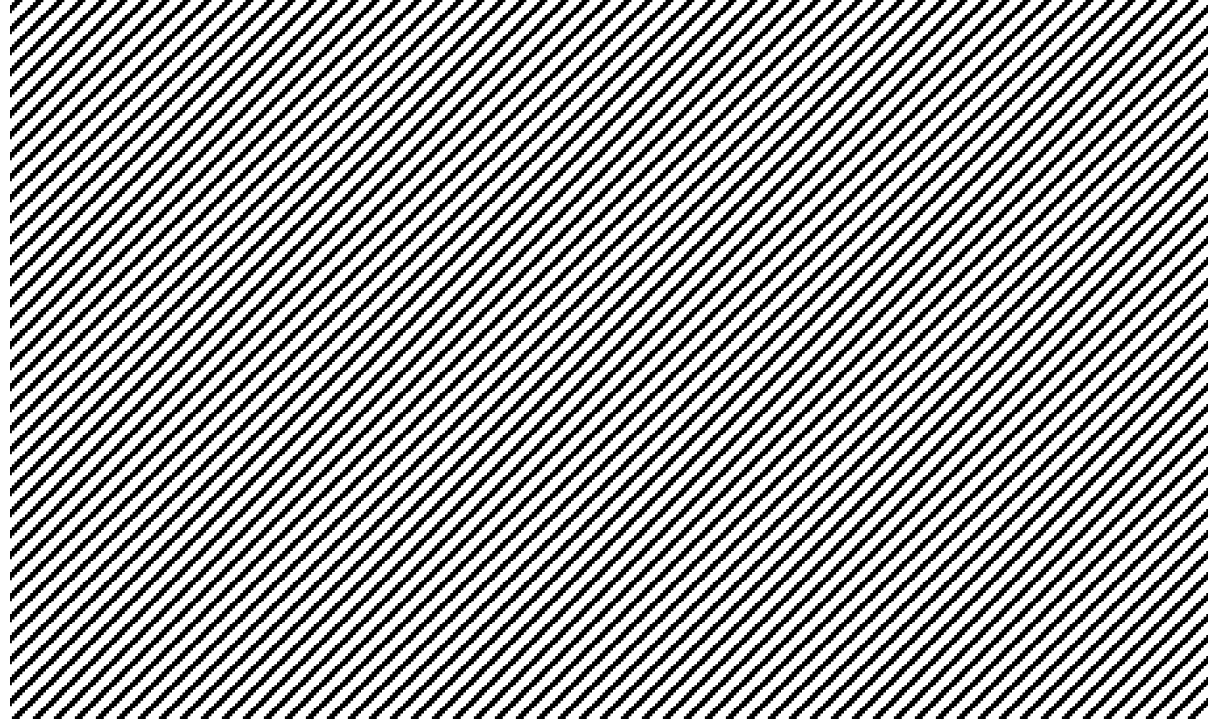

Figure 10. Strength reduction in the sulfate attack test as a function of partial replacement.

\subsubsection{Freeze and Thaw}

Frost action, or freeze and thaw, is one of the main reasons for the deterioration of bricks in historical buildings situated in cold regions [38]. Ice owing to the larger volume exerts internal stresses that crack the bricks. In the current study, a freeze-and-thaw test was performed according to ASTM C67-17. The test results are shown in Figure 11. The minimum $(0.87 \%)$ effect of freeze and thaw was observed in $\mathrm{C} 45$, whereas the maximum $(0.96 \%)$ was seen in C1215. ASTM C67 declares a weight loss of more than 3\% as a "fail" [4]. Hence, the composite mixture of WBP and WCP (up to $27 \%$ ) was resistant to freeze-andthaw action. 


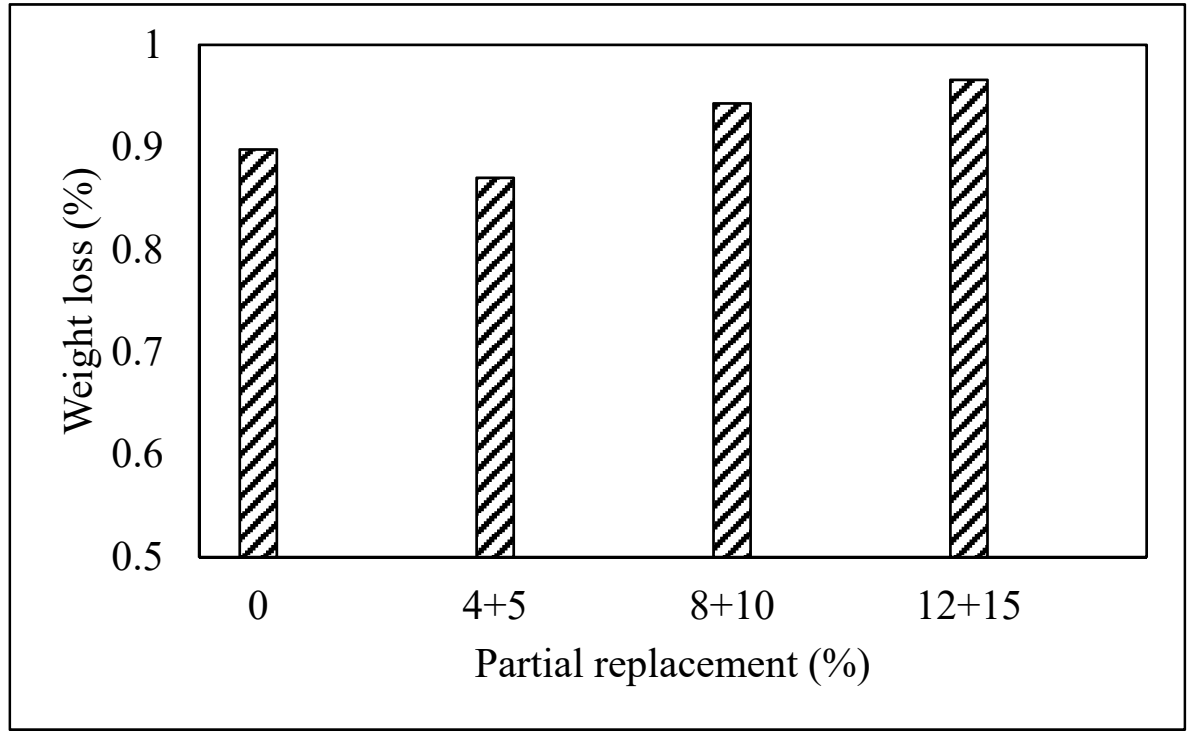

Figure 11. Variation of weight loss as a function of partial replacement in the freeze-and-thaw test.

\subsubsection{Chemical Resistance of Bricks}

ASTM C-67 was used to check the chemical resistance of bricks. One end of the dried and cooled bricks was exposed to a depth of $38 \mathrm{~mm}$ in a $10 \%$ solution of hydrochloric acid $(\mathrm{HCl})$ for $3 \mathrm{~h}$. The opposite end of the bricks was submerged to the same depth in a $10 \%$ solution of potassium hydroxide $(\mathrm{KOH})$ solution for $3 \mathrm{~h}$. No color or texture change was observed in either the control or modified specimens. Both the control and modified specimens were found to be inert.

\subsection{Mechanical Properties}

\subsubsection{Compressive Strength}

The compressive strength of the bricks was determined according to ASTM C-67 [27] and is shown in Figure 12. The results seem to be the reflection of the porosity results shown in Figure 7. As the porosity increased, the strength also increased and vice versa.

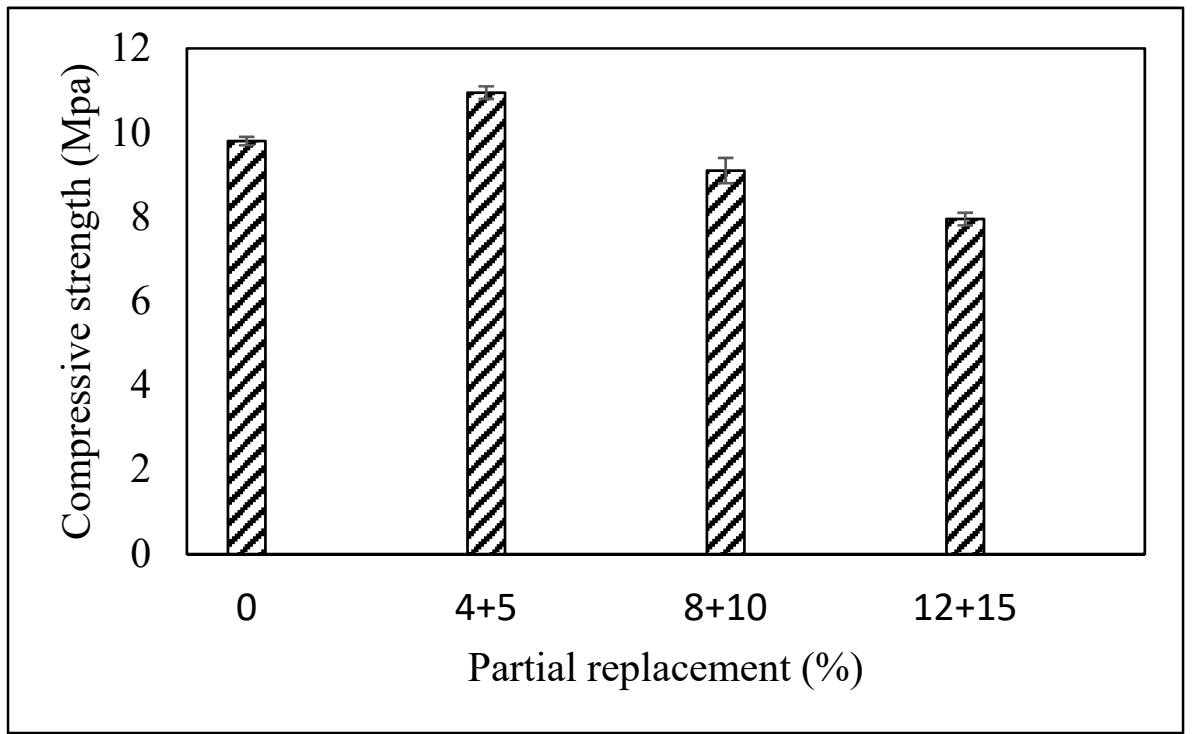

Figure 12. Variation of compressive strength with partial replacement.

Riaz et al. reported a compressive strength of 7.92 $\mathrm{MPa}$ and $10.72 \mathrm{MPa}$ for specimens with only $15 \% \mathrm{WBP}$ and $12 \% \mathrm{WCP}$, respectively. The combined mixture $(12+15) \%$ resulted 
in a compressive strength of $8.1 \mathrm{MPa}$, which reported a slight increase in compressive strength with the addition of $12 \%$ WCP to $15 \%$ WBC. However, $7.92 \mathrm{MPa}$ strength was obtained with $15 \%$ WBP and $85 \%$ clay, whereas 8.1 MPa strength was achieved with $15 \%$ $\mathrm{WBP}, 12 \% \mathrm{WCP}$, and $73 \%$ clay and is, therefore, more ecological and green than the former one. The highest strength of $11 \mathrm{MPa}$ was obtained with a $(4+5) \%$ mixture and was more than $10 \mathrm{MPa}$ (threshold for first-class bricks). The second-class types had a minimum compressive strength of $7 \mathrm{MPa}$ and water absorption of 25\% [39]. Except for C45, all other bricks were second-class bricks suitable for external and internal walls without plastering. The first-class bricks are additionally recommended for flooring.

\subsubsection{Modulus of Rupture}

The MOR of the bricks was determined according to ASTM C-67. The results are shown in Figure 13. The maximum MOR of 3.3 MPa was obtained with C45, whereas the minimum was $1.84 \mathrm{MPa}$ with C1215. The minimum MOR as specified by the Building Code of Pakistan, ASTM C67, and Indian Standards was 1 MPa [10,40]. Hence, all the bricks met the minimum MOR as recommended by the building codes.

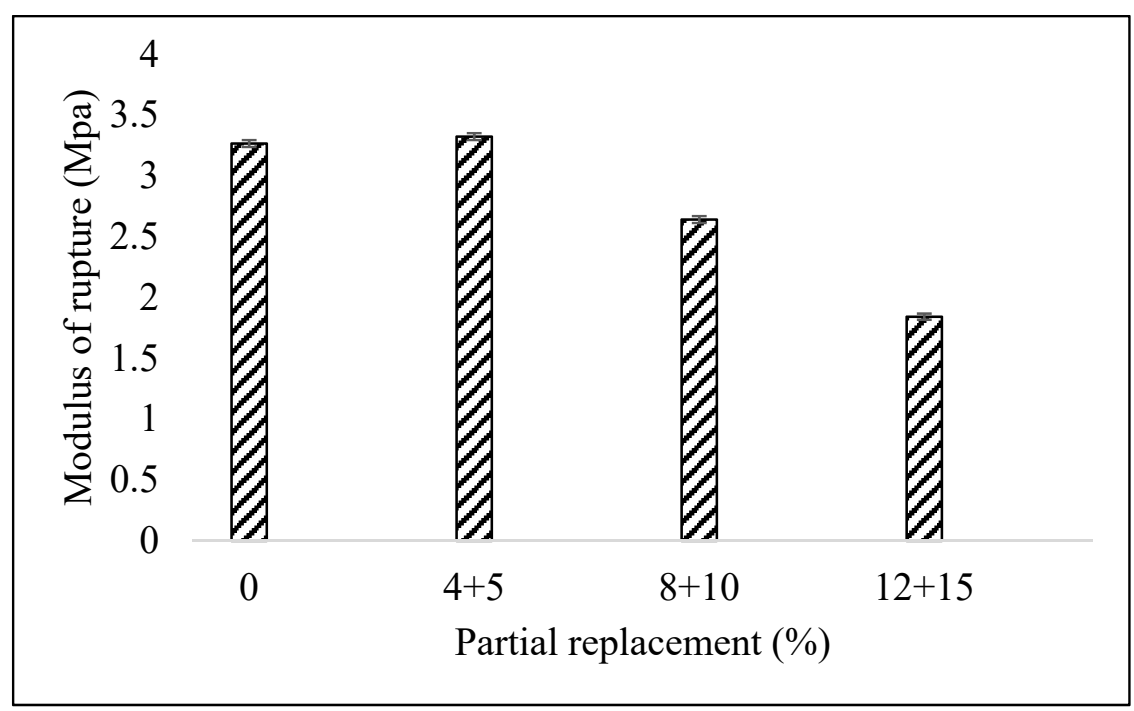

Figure 13. Variation of the modulus of rupture with partial replacement.

\section{Conclusions}

Hazardous impacts of construction activities have forced researchers to innovate new ways to ensure the sustainable development of future generations. As the conservation of natural resources is a significant part of sustainability, recycling waste is a rational, logical, and economical step towards conserving these resources. The results indicated that brick and ceramic wastes are suitable for being used as a clay replacement in manufacturing bricks. The following conclusions have been drawn from the study:

- Bricks containing waste ceramic and brick powder were free of efflorescence and had equal resistance against chemical attack, as observed in the ASTM C67 standard test.

- Bricks containing $27 \%(15 \% \mathrm{WBP}+12 \% \mathrm{WCP})$ waste materials possessed the same density, porosity, and water absorption capacity as those containing $100 \%$ clay.

- Bricks containing $27 \%(15 \% \mathrm{WBP}+12 \% \mathrm{WCP})$ waste materials possessed a $27 \%$ decreased initial water absorption rate compared to the control specimens.

- $\quad$ Bricks with $9 \%(5 \% \mathrm{WBP}+4 \% \mathrm{WCP})$ waste materials had a compressive strength of 11 $\mathrm{MPa}$, more than the control specimens with 9.8 MPa strength. However, bricks with $27 \%$ waste materials had a strength of $8.1 \mathrm{MPa}$.

- Bricks with $9 \%(5 \% \mathrm{WBP}+4 \% \mathrm{WCP})$ waste materials had a modulus of rupture of $3.32 \mathrm{MPa}$, more than that of the control specimens with $3.26 \mathrm{MPa}$ strength. However, bricks with $27 \%$ waste materials had a strength of $1.84 \mathrm{MPa}$. 
- The combination of waste brick and ceramic powder was effective against sulfate attack, and the resistance increased with an increase in the replacement level.

- Bricks with $9 \%(5 \% \mathrm{WBP}+4 \% \mathrm{WCP})$ waste materials showed the highest resistance against freeze and thaw (only $0.87 \%$ weight loss). Nevertheless, the weight loss in all the specimens was found to be less than $1 \%$.

Based on the current study, it is concluded that $27 \%$ mass of clay can be successfully replaced with $12 \%$ waste ceramic powder and $15 \%$ waste brick powder. The resulting end products show characteristics similar to the control specimens and overcome the deficiencies arising from using unary replacement either by waste brick powder or waste ceramic powder.

Author Contributions: Conceptualization, A.K. and R.B.N.K.; software, M.S.R. and R.B.N.K.; validation, A.K., M.S.K. and A.J.; formal analysis, R.A.K. and A.K.; investigation, M.S.K., R.B.N.K., M.T.A. and W.A.; resources, Z.T. and S.T.; writing-original draft preparation, A.K., M.S.R., R.B.N.K., A.J. and S.T.; writing-review and editing, A.K.; visulization, A.K.; supervision, A.K. and R.A.K.; project administration, A.K., R.B.N.K.,A.J., Z.T. All authors have read and agreed to the published version of the manuscript.

Funding: This research received no external funding.

Institutional Review Board Statement: Not applicable.

Informed Consent Statement: Not applicable.

Data Availability Statement: The study did not report any data.

Acknowledgments: The authors are thankful to Asad Hanif and Junaid Tariq of the department of Civil Engineering, Mirpur University of Science and Technology (MUST) for providing assistance regarding correction of English language and evaluation of the effect of the mineralogical composition on the characteristics of the finished products.

Conflicts of Interest: The authors declare no conflict of interest.

\section{References}

1. Horta, I.M.; Camanho, A.S.; Johnes, J.; Johnes, G. Performance trends in the construction industry worldwide: An overview of the turn of the century. J. Product. Anal. 2013, 39, 89-99. [CrossRef]

2. Khitab, A.; Anwar, W. Advanced Research on Nanotechnology for Civil Engineering Applications; IGI Global: Hershey, PA, USA, 2016; pp. 1-27.

3. Aakash, S.P. Engineering Properties of Clay Bricks with Use of Ash. Int. J. Res. Eng. Technol. 2014, 3, 75-80. [CrossRef]

4. Riaz, M.H.; Khitab, A.; Ahmad, S.; Anwar, W.; Arshad, M.T. Use of ceramic waste powder for manufacturing durable and eco-friendly bricks. Asian J. Civ. Eng. 2019. [CrossRef]

5. Cultrone, G.; Sebastián, E.; Elert, K.; de la Torre, M.J.; Cazalla, O.; Rodriguez-Navarro, C. Influence of mineralogy and firing temperature on the porosity of bricks. J. Eur. Ceram. Soc. 2004, 24, 547-564. [CrossRef]

6. Singh, G. Building Construction and Materials; Standard Book House: Delhi, India, 2018.

7. Ion, R.-M.; Fierascu, R.-C.; Teodorescu, S.; Fierascu, I.; Bunghez, I.-R.; Turcanu-Carutiu, D.; Ion, M.-L. Clays, Clay Minerals and Ceramic Materials Based on Clay Minerals; InTech: London, UK, 2016; pp. 159-184.

8. Cultrone, G.; Sidraba, I.; Sebastian, E. Mineralogical and physical characterization of the bricks used in the construction of the bTriangul BastionQ, Riga (Latvia). Appl. Clay Sci. 2005, 28, 297-308. [CrossRef]

9. Andreola, F.; Lancellotti, I.; Manfredini, T.; Bondioli, F.; Barbieri, L. Rice Husk Ash (RHA) Recycling in Brick Manufacture: Effects on Physical and Microstructural Properties. Waste Biomass Valorization 2018, 9, 2529-2539. [CrossRef]

10. Kazmi, S.M.S.; Abbas, S.; Munir, M.J.; Khitab, A. Exploratory study on the effect of waste rice husk and sugarcane bagasse ashes in burnt clay bricks. J. Build. Eng. 2016, 7, 372-378. [CrossRef]

11. Ibrahim, J.E.F.M.; Tihtih, M.; Gömze, L.A. Environmentally-friendly ceramic bricks made from zeolite-poor rock and sawdust. Constr. Build. Mater. 2021, 297, 123715. [CrossRef]

12. Ahmad, S.; Iqbal, Y.; Muhammad, R. Effects of coal and wheat husk additives on the physical, thermal and mechanical properties of clay bricks. Bol. Soc. Esp. Ceram. Vidr. 2017, 56, 131-138. [CrossRef]

13. Munir, M.J.; Abbas, S.; Nehdi, M.L.; Kazmi, S.M.S.; Khitab, A. Development of eco-friendly fired clay bricks incorporating recycled marble powder. J. Mater. Civ. Eng. 2018, 30. [CrossRef]

14. Mandal, A.K.; Sinha, O.P. Preparation and Characterization of Fired Bricks Made from Bottom Ash and Iron Slime. J. Mater. Civ. Eng. 2017, 29, 4016245. [CrossRef] 
15. Hasan, M.R.; Siddika, A.; Akanda, M.P.A.; Islam, M.R. Effects of waste glass addition on the physical and mechanical properties of brick. Innov. Infrastruct. Solut. 2021, 6, 36. [CrossRef]

16. Li, R.; Zhou, Y.; Li, C.; Li, S.; Huang, Z. Recycling of industrial waste iron tailings in porous bricks with low thermal conductivity. Constr. Build. Mater. 2019, 213, 43-50. [CrossRef]

17. Jiménez-Quero, V.G.; Guerrero-Paz, J.; Ortiz-Guzmán, M. Alternatives for improving the compressive strength of clay-based bricks. J. Phys. Conf. Ser. 2021, 1723, 012027. [CrossRef]

18. Jordan, M.M.; Montero, M.A.; Meseguer, S.; Sanfeliu, T. Influence of firing temperature and mineralogical composition on bending strength and porosity of ceramic tile bodies. Appl. Clay Sci. 2008, 42, 266-271. [CrossRef]

19. Montero, M.A.; Jordán, M.M.; Hernández-Crespo, M.S.; Sanfeliu, T. The use of sewage sludge and marble residues in the manufacture of ceramic tile bodies. Appl. Clay Sci. 2009, 46, 404-408. [CrossRef]

20. Montero, M.; Jordan, M.; Almendrocandel, M.; Sanfeliu, T.; Hernandezcrespo, M. The use of a calcium carbonate residue from the stone industry in manufacturing of ceramic tile bodies. Appl. Clay Sci. 2009, 43, 186-189. [CrossRef]

21. Riaz, M.H.; Khitab, A.; Ahmed, S. Evaluation of sustainable clay bricks incorporating Brick Kiln Dust. J. Build. Eng. 2019, 24, 100725. [CrossRef]

22. Munir, M.J.; Kazmi, S.M.S.; Wu, Y.-F.; Hanif, A.; Khan, M.U.A. Thermally efficient fired clay bricks incorporating waste marble sludge: An industrial-scale study. J. Clean. Prod. 2018, 174, 1122-1135. [CrossRef]

23. Kazmi, S.M.S.; Munir, M.J.; Wu, Y.-F.; Hanif, A.; Patnaikuni, I. Thermal performance evaluation of eco-friendly bricks incorporating waste glass sludge. J. Clean. Prod. 2018, 172, 1867-1880. [CrossRef]

24. Vyšvařil, M.; Rovnaníková, P.; Keppert, M. Rheological Properties of Alkali-Activated Brick Powder Based Pastes: Effect of Alkali Activator and Silicate Modulus. Solid State Phenom. 2018, 276, 185-191. [CrossRef]

25. Material-Specifications. Available online: http://cwd.gkp.pk/images/CSR/Material-Specifications-MRS-KPK-2020.pdf (accessed on 9 September 2021).

26. Pakistan Engineering Council. Standardization of Building Codes, Standards and Specifications for Low-Cost (Affordable) Units. Available online: https:/ / pec.org.pk/downloads/Standardization\%20of\%20Building\%20Codes, \%20Standards\%20and \% 20Specifications\%20for\%20Low-Cost\%20(Affordable)\%20Units-2021.pdf (accessed on 7 September 2021).

27. ASTM C67/C67M-21. Standard Test Methods for Sampling and Testing Brick and Structural Clay Tile; ASTM International: West Conshohocken, PA, USA, 2014.

28. ASTM C1012/C1012M-15. Standard Test Method for Length Change of Hydraulic-Cement Mortars Exposed to a Sulfate Solution; ASTM International: West Conshohocken, PA, USA, 2015; pp. 5-9.

29. Ahmed, M.; Mallick, J.; Hasan, M.A. A study of factors affecting the flexural tensile strength of concrete. J. King Saud Univ. Eng. Sci. 2016, 2016, 147-156. [CrossRef]

30. ASTM C20-00. Standard Test Methods for Apparent Porosity, Water Absorption, Apparent Specific Gravity, and Bulk Density of Burned Refractory Brick and Shapes by Boiling Water; ASTM International: West Conshohocken, PA, USA, 2015.

31. Sutcu, M.; Alptekin, H.; Erdogmus, E.; Er, Y.; Gencel, O. Characteristics of fired clay bricks with waste marble powder addition as building materials. Constr. Build. Mater. 2015, 82, 1-8. [CrossRef]

32. Abhilash, J. IS: 875 (Part 1)-1987 Indian Standard PART 1 DEAD LOADS-UNIT WEIGHTS OF BUILDING MATERIALS AND STORED MATERIALS B U R E A U O F I N D I A N S T A N D A R D S. Available online: https: //www.academia.edu/6224449/IS_875_Part_1_1987_Indian_Standard_PART_1_DEAD_LOADS_UNIT_WEIGHTS_OF_ BUILDING_MATERIALS_AND_STORED_MATERIALS_B_U_R_E_A_U_O_F_I_N_D_I_A_N_S_T_A_N_D_A_R_D_S (accessed on 7 September 2021).

33. Khitab, A. Finite Element Analysis of Structural Concrete Insulated Panels Subjected to Dynamic Loadings. Civ. Eng. Beyond Limits 2020, 1, 31-37. [CrossRef]

34. Bakar, B.H.A.; Saari, S.; Surip, N.A. Water absorption characteristic of interlocking compressed earth brick units. AIP Conf. Proc. 2017, 1892, 020018. [CrossRef]

35. ASTM C62-13. Standard Specification for Building Brick (Solid Masonry Units Made from Clay or Shale); ASTM International: West Conshohocken, PA, USA, 2013.

36. Pavía, S.; Hanley, R. Flexural bond strength of natural hydraulic lime mortar and clay brick. Mater. Struct. 2010, 43, 913-922. [CrossRef]

37. Khitab, A.; Lorente, S.; Ollivier, J.P. Predictive model for chloride penetration through concrete. Mag. Concr. Res. 2005, 57, 511-520. [CrossRef]

38. Stryszewska, T.; Kańka, S. Forms of Damage of Bricks Subjected to Cyclic Freezing and Thawing in Actual Conditions. Materials 2019, 12, 1165. [CrossRef]

39. Akinyele, J.O.; Igba, U.T.; Ayorinde, T.O.; Jimoh, P.O. Structural efficiency of burnt clay bricks containing waste crushed glass and polypropylene granules. Case Stud. Constr. Mater. 2020, 13, e00404. [CrossRef]

40. Sharma, N.; Telang, D.; Rath, B. A Review on Strength of Clay Brick Masonry. Int. J. Res. Appl. Sci. Eng. Technol. 2017, 5, 2620-2626. 